\title{
Russian City in Siberia of the 17th and 18th Centuries: Stages of Formation and Typology of Buildings in Yeniseisk
}

\author{
Vladimir I. Tsarev ${ }^{1, *}$ Vladimir V. Tsarev ${ }^{2, a}$ \\ ${ }^{1}$ Chief Researcher of the Department of Reconstruction and Restoration of Historical and Architectural \\ Heritage NIITIAG, Doctor of Architecture, Professor of the Department of Urban Planning of the Institute of \\ Architecture and Design of the Siberian Federal University, Moscow-Krasnoyarsk, Russia \\ ${ }^{2}$ Senior Researcher of the Department of Reconstruction and Restoration of Historical and Architectural \\ Heritage NIITIAG, Candidate of Architecture, Consultant of the Department of Urban Development of the \\ Ministry of Construction of the Krasnoyarsk territory, Moscow-Krasnoyarsk, Russia \\ ${ }^{a}$ E-mail: tsarev103@yandex.ru \\ *Corresponding author. E-mail: vits_2004@mail.ru
}

\begin{abstract}
The formation of Russian fortresses and settlements in Siberia of the 17th and 18th centuries has been little studied. Based on archival documents, the typology of military objects, residential and household buildings in the first Russian city of Central Siberia - Yeniseisk is revealed. The process of forming the architectural and planning structure of the Yenisei Ostrog is considered. The planning features of urban courtyards - the main structural cells of Siberian settlements-are defined. The architectural aspects of construction of wooden residential and household buildings in the first Russian cities of Siberia are revealed. Graphic reconstruction of urban development objects has been completed.
\end{abstract}

Keywords: Planning history, Siberia, History of urban construction, Russian fortress cities, Wooden architecture, Yeniseisk.

\section{INTRODUCTION}

In 2019, Yeniseisk noted celebrate its 400th anniversary. It is the first Russian city in Central Siberia, which was founded in 1619 . In the 17th and 18th centuries, a waterway ran through Yeniseisk, connecting the Russian state with the new Eastern territories. However, the architectural and town-planning chronicle of Yeniseisk itself remains incomplete. Many documentary sources about the initial period of construction of the city have not been identified and studied. The process of forming Yeniseisk as a military fortress, covering the 17th and 18th centuries, allows us to trace in sufficient detail the identified documents, stored in the Russian state archive of ancient acts.

\section{STAGES OF FORMATION OF THE FIRST RUSSIAN CITY ON THE YENISEI RIVER}

In the 17th century, the main Russian settlements on the banks of the largest Siberian rivers $\mathrm{Ob}$ and Yenisei were wooden fortresses, which were called 'Ostrog' (after the type of fortress walls made of a stockade of pointed $\operatorname{logs}$ ). One of them was the Yenisei 'Ostrog'. Documentary descriptions of the fortress, built in 1619 on the left bank of the Yenisei by a Russian military detachment led by the 'son of the boyar' (the social layer in Russia of the 17th century) Peter Albychev and the 'Cossack' (military person) Cherkas Rukin, remain unidentified to this day. According to the 18th-century historian G. F. Miller, 'at first it was only a small quadrangular Ostrog' [1]. 
The first expansion of the fortress was associated with the 'voivode' (military and administrative chief) Yakov Khripunov. He reported to Tsar Mikhail Fyodorovich: 'I came to Yeniseisk in 1623; the Ostrog was all rotten and fell down; he set up a new Ostrog and added ten sazhens in all directions to the old Ostrog; the Ostrog and the towers were strongly fortified; on those towers raskat did' [2]. In the 17 th century, the main measure of length was 'sazhen' (Russian unit of length measurement), equal to 2.16 meters and containing three 'arshin' (Russian unit of length measurement $-72 \mathrm{~cm}$ ). The 'raskat' was a wooden platform for the placement of the cannons.

In 1626 'voivode' Andrey Oshanin wrote about the buildings of this 'Ostrog' in Tobolsk: 'In the Yenisei Ostrog 2 towers with gates; on one tower raskat; there's a gate on the wall; at the corners of the Ostrog instead of towers there are two izba; the raskat are built on them' [3]. The ' $i z b a$ ' differed from the battle tower in that its wooden frame had a residential heated room. According to the 'voivode', there were military man in the fortress in the number of two 'atamans' (military leader), five centurions and 105 'streltsy' (a military man with a firearm).

In a petition to Tsar Mikhail Fedorovich dated 1626, 'voivode' Andrey Oshanin reported on the first two wooden churches built in Yeniseisk. The 'voivode' asked to send icons, Church books and bells to the built churches [4].

The humid climate, frequent floods and fires brought the wooden Yeniseisk to a dilapidated state. For example, in 1647, 'voivode' Fyodor Polybinus informed Tsar Alexey Mikhailovich that when taking the fortress under his leadership, he found destroyed fortifications. This is the first identified source that provides information about the size of the Yenisei fortress of the 17th century. 'Around that Ostrog two hundred sazhens; it is seventy-four sazhens long in the middle of the Ostrog; transverse size at the upper end of the twenty-one sazhen; at the lower end the cross size is eighteen sazhens' [5].

In modern units of measurement, the perimeter of the walls is $2.16 \mathrm{~m} \times 200 \mathrm{~s}=432 \mathrm{~m}$; the length of the fortress along the middle line is $2.16 \mathrm{~m} \times 74$ $\mathrm{s}=159.84 \mathrm{~m}$; the width at the upper end, that is, upstream of the Yenisei, was equal to $2.16 \mathrm{~m} \times 21 \mathrm{~s}$ $=45.36 \mathrm{~m}$; on the lower, down the river $-2.16 \mathrm{~m} \times$ $18 \mathrm{~s}=38.88 \mathrm{~m}$.
In the early 1650s, under 'voivode' Afanasy Pashkov, the Yenisei 'Ostrog' was rebuilt. The size of the wooden fortress increased and new towers were built. However, researchers have not been able to identify archival documents that would describe information about the construction work itself, which is one of the mysteries of the history of Yeniseisk. In the lists of city buildings for the second half of the seventeenth century, it was repeatedly pointed out that 'the Yenisei Ostrog is the building of voivode Afanasy Pashkov, and the Ostrog has six passing towers and two deaf towers' [6].

By the middle of the 17th century, residential buildings of Yeniseisk went beyond the walls of the fortress, where the 'Posad' (trade and craft part of the Russian city) began to form. In 1667, under the 'voivode' Kirill Yakovlev, new fortifications were built, located above the old 'Ostrog' beyond the Mill River. They had a length of eight hundred and twenty five 'sazhens' and six towers. Graphic reconstruction of the system of fortifications of Yeniseisk in 1667 was performed by the authors in a previously published article [7]. The borders of the big and small 'Ostrogs' were preserved until the end of the 17th century, but the fortifications gradually deteriorated. For example, the inventory of 1699 read: 'The Yenisei Ostrog has eight towers; it has rotted and fallen apart from many years' [8].

In the first years of the 18th century, the defensive fortifications of Yeniseisk still retained the external features introduced from the last century. The city list for 1702 states: 'The Yenisei Ostrog has eight towers, including six towers with passing gates, two towers are deaf; the length of the Ostrog is six hundred and eighty-five sazhens' [9].

On September 19, 1703, a large fire occurred in Yeniseisk, in which many buildings of the wooden city were destroyed, including the 'old Ostrog of five hundred and six sazhens; five towers were burned' [10]. In 1704, most of the fortress towers and walls that were burned down in a fire were restored to their former planning boundaries. In the inventory for 1705 it is written: 'The new Yenisei Ostrog has eight towers, including three old towers and five new towers; the length of the Ostrog is six hundred and eighty-two sazhens' [11].

In 1733, according to the historian G. F. Miller, the fortifications of Yeniseisk were updated [12]. About the results of construction work and the state of the fortress, there is information in the inventory of Yeniseisk for 1741. 
'The city of Yeniseisk is located on the Yenisei river. The city is surrounded by a new palisade (of vertical $\operatorname{logs}$ ); the length of the palisade is one thousand six hundred and forty-three sazhens and a half. In the new palisade, seven towers were built, including five towers with passing gates. The old palisade is dilapidated, one hundred and ninetynine sazhens and a half long. The old palisade has four towers; three with drive-through gates' [13].

In the second half of the 18th century, Yeniseisk lost the significance of a military fortress, the buildings of which continued to disappear. According to documents from the 1770 s, the small town was enclosed by a wooden 'palisade' with towers, which had a length of 250 'sazhens'. 'The palisade fell apart long ago, and there are only three towers. Beyond the borders of the city there is a palisade with towers; the palisade has fallen out in many places, and there are six towers' [14].

In the topographical description of the Tobolsk Viceroyalty, compiled in 1790 , it was reported that in Yeniseisk 'there are no fortifications near the city, although until 1778 there were on three sides a palisade with nine wooden towers, but part of the dilapidation, and part of the former great fire burned out' [15].

At the turn of the 17th and 18th centuries, there were constructive and compositional methods of building Siberian wooden fortresses, based on the age-old traditions of Russian architecture and proven by decades of fighting in new conditions. The Yenisei 'Ostrog' included in its threedimensional composition most of the characteristic elements of the Siberian defense architecture. This is the choice of the location of the fortress in relation to the large and small rivers, a type of fortress walls that are being built quickly, squareplan log towers covered with four-pitched roofs. Therefore, Yeniseisk became a model for the construction of new fortresses on the Eastern borders of the Russian state.

The study was the first to reconstruct the historical picture of the formation of Yeniseisk as the first Russian fortress in Central Siberia. However, the features and typology of residential buildings of the first Russian cities in Siberia, including Yeniseisk, remained poorly studied.

\section{PLANNING AND CONSTRUCTION OF CITY COURTYARDS OF YENISEISK AT THE TURN OF THE 17TH AND 18TH CENTURIES}

A unique archival document allows us to judge the residential buildings of the first Russian cities in Siberia - 'Census book of Inns of Yeniseisk', compiled in 1704 [16]. It describes residential and household buildings located in 33 courtyards on the territory of the city, the owners of which were 'Posadsky' people, ordinary foot 'Cossacks', artisans, as well as the 'son of a boyar' (one yard). The value of the census book for our research is that it indicates the size of courtyards and vegetable garden, the types of houses and household buildings, their sizes, as well as building materials and partially construction techniques. For example, let's give an excerpt from the text of the book containing a description of one of the city's courtyards: 'There is a residential building in the courtyard - a new izba three sazhens long without a arshin; in front of the $i z b a$ there is a seni (entrance room in the house), which are made of Drani (split boards); in the same courtyard the old hay barn; the yard is nineteen sazhens long and five sazhens across' [17]. Information about the typology of ordinary buildings in Yeniseisk, given in the census book, was systematized in the "Table 1" and ("Figure 1") (a description of the old terms is given in the following paragraph). Graphic reconstruction of the layout of objects, performed by the authors, reveals the features of residential and household buildings united by courtyard spaces. 
Table 1. Typology of yard buildings of the city of Yeniseisk in 1704

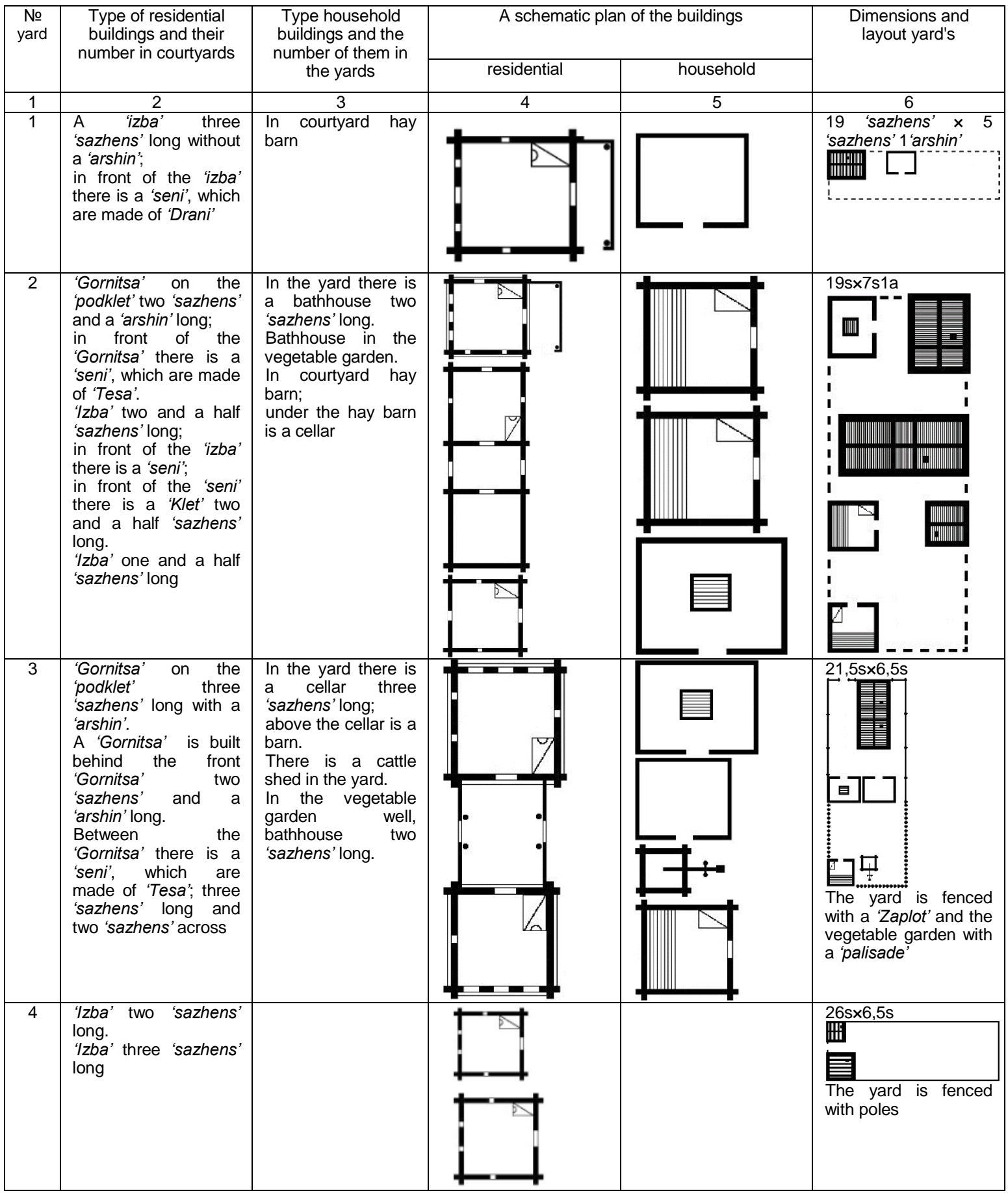




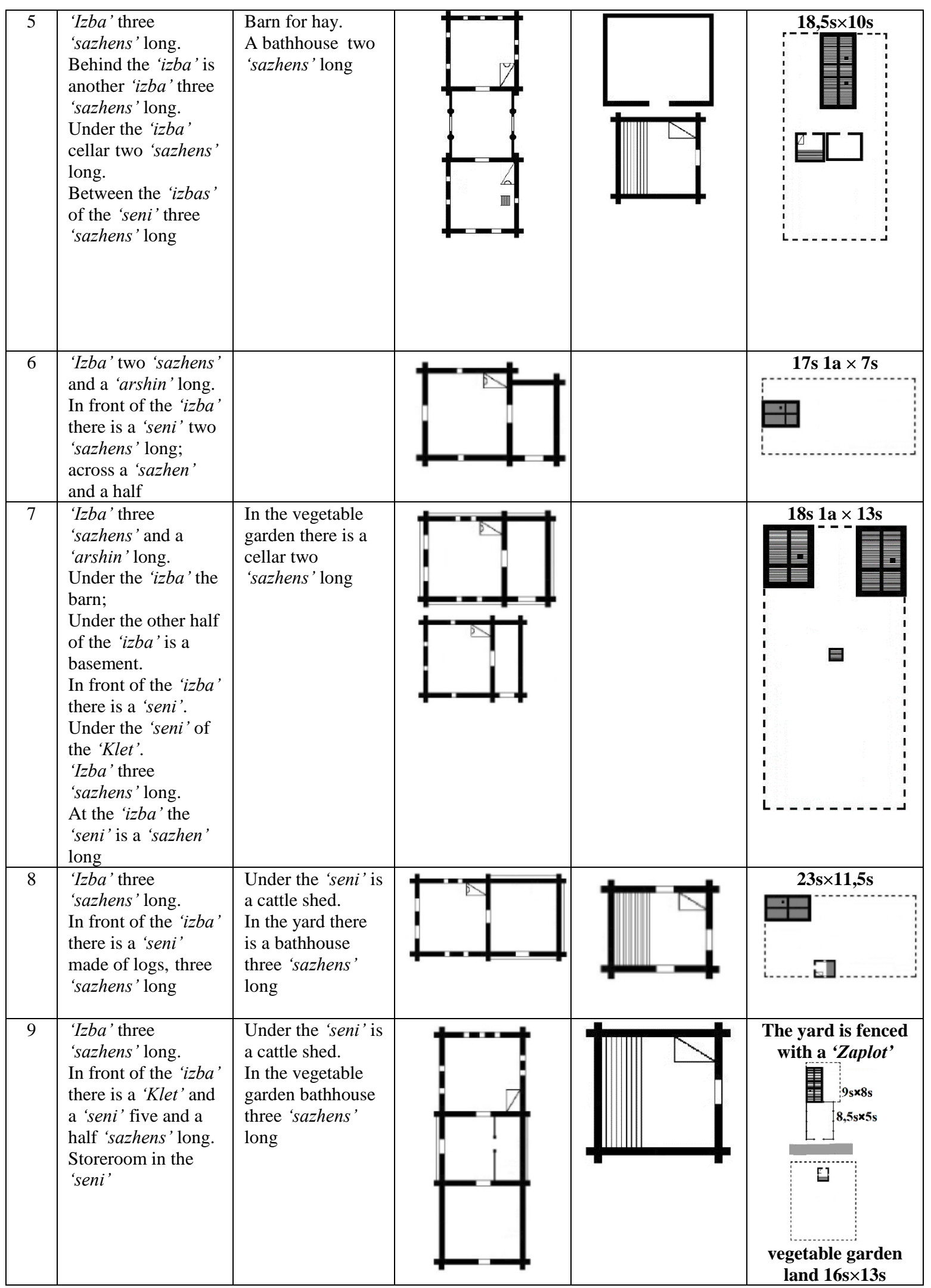




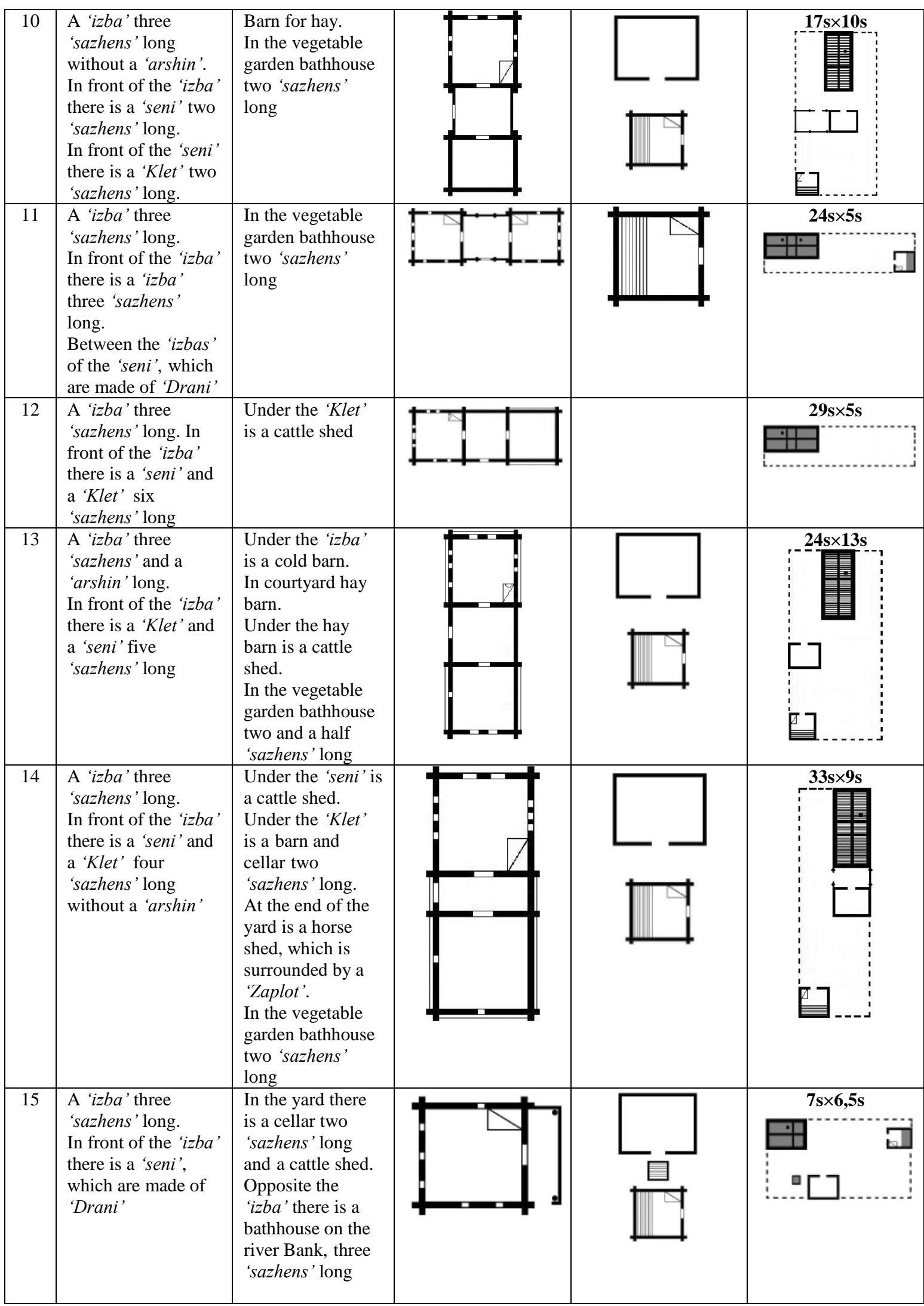




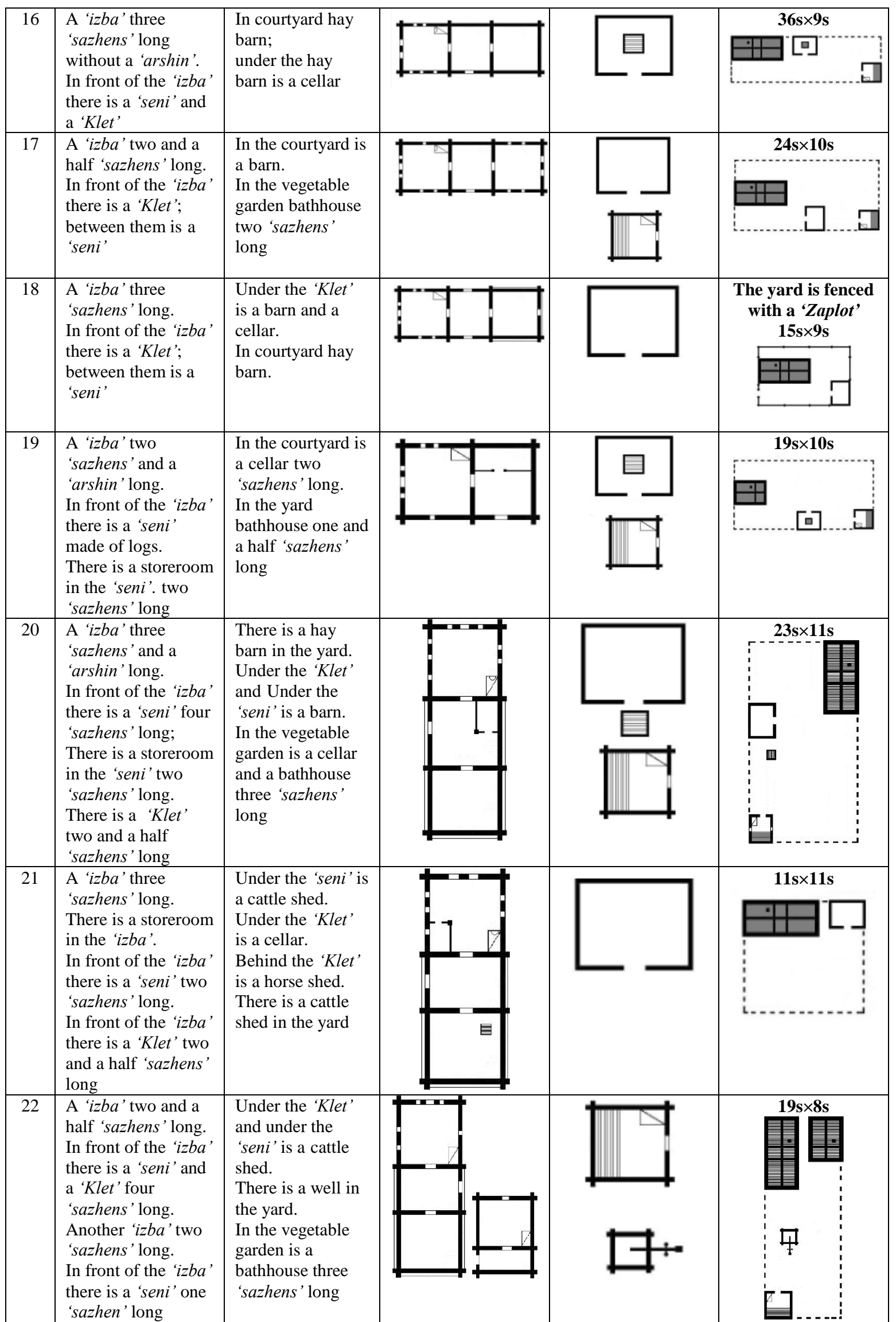




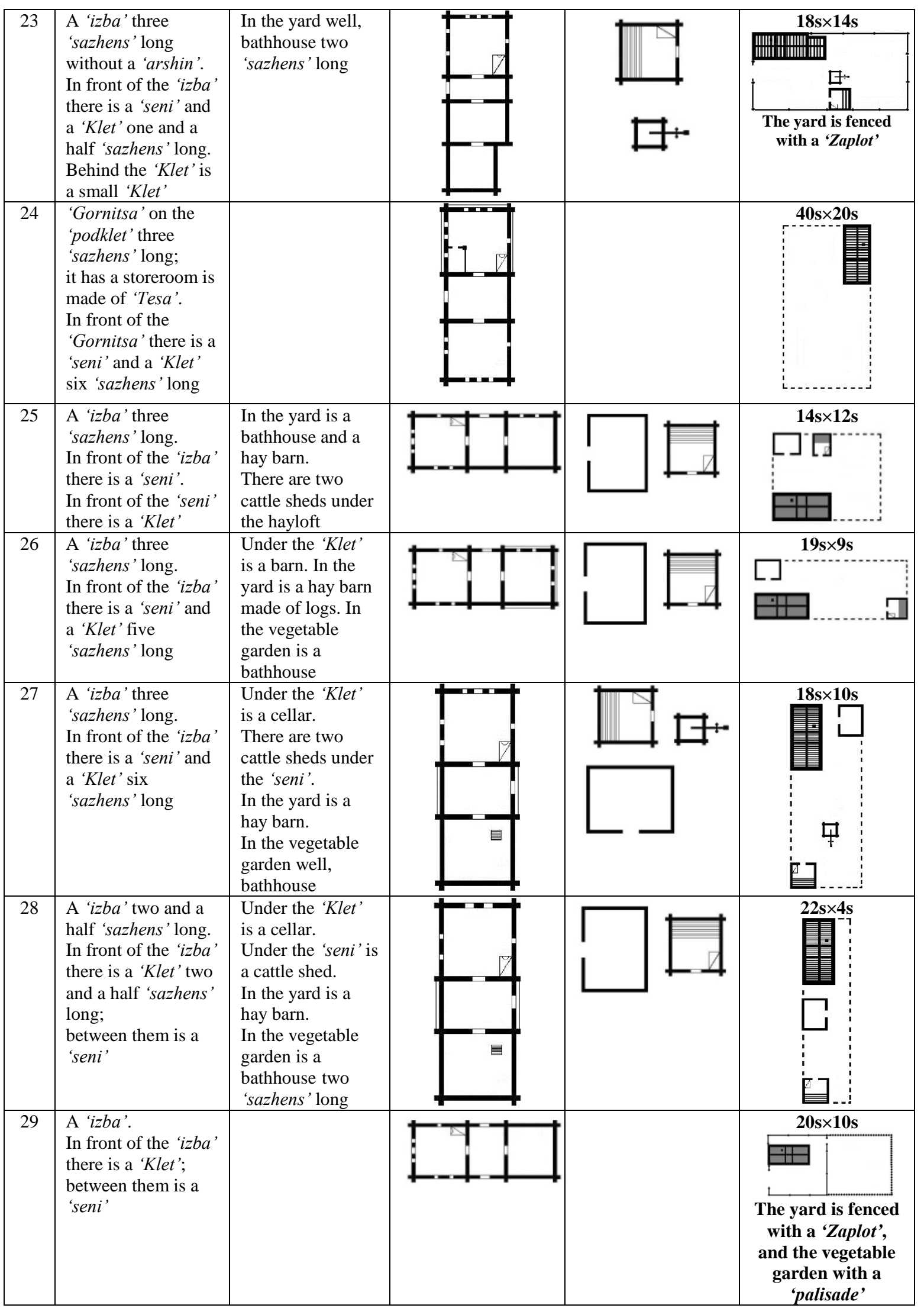




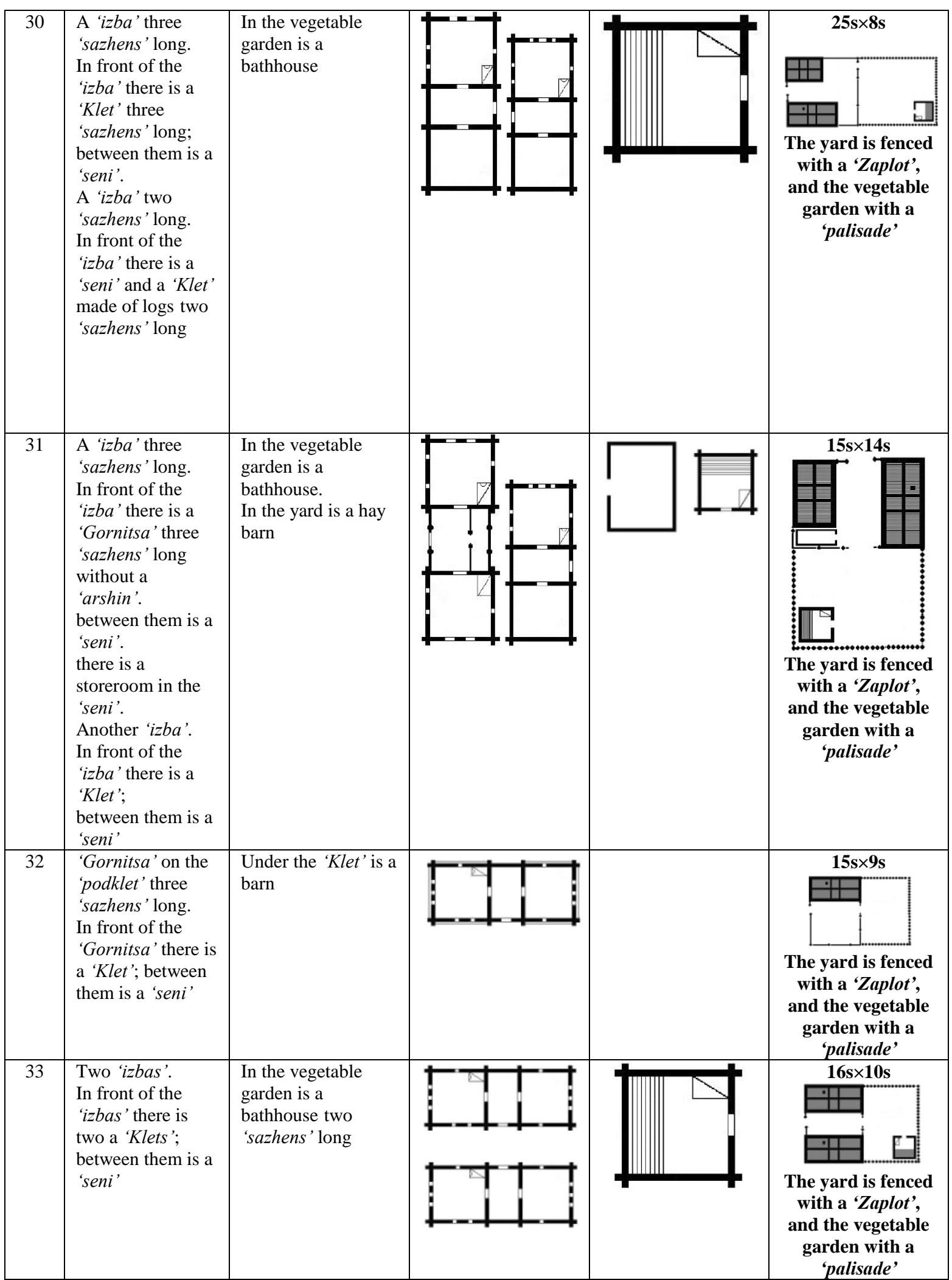



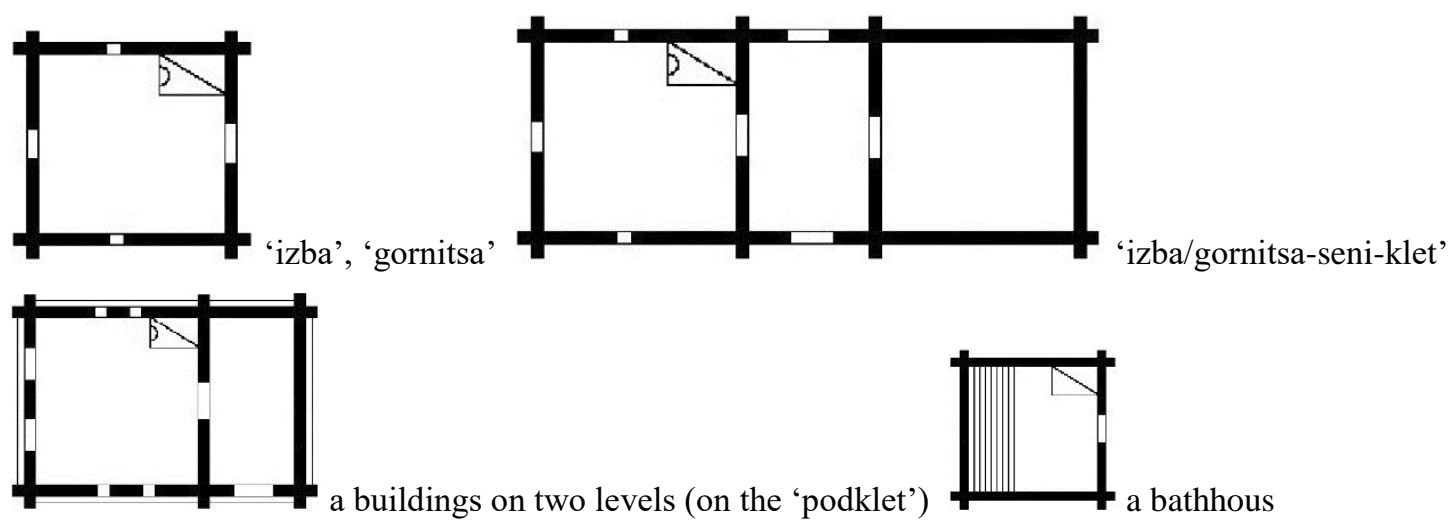

a bathhous

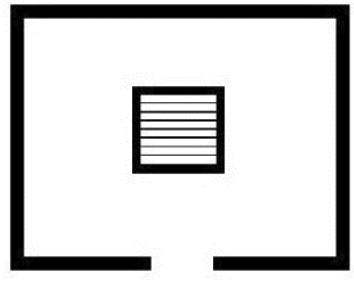

a barn, a hay barn, a barn with a cellar

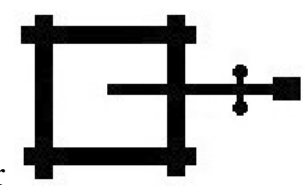

a well

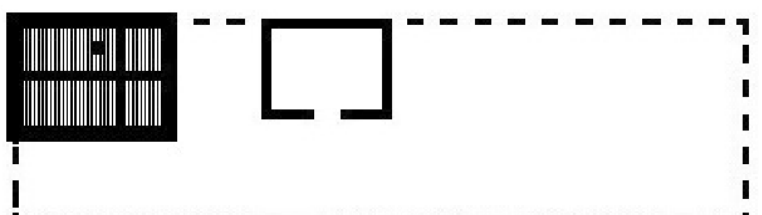

yard without specifying the type of fence

Figure 1 Conventional Signs.

\section{CONCLUSION}

Materials of the census book indicate that at the beginning of the 18th century in Yeniseisk, the main structural units of the city were yard plots, the area of which had a significant size (from 600 to 1500 square meters). A significant part of the yard area was occupied by vegetable gardens, which completed the territory of the residential and economic complex. The structure of the residential building has a second warm room - the 'gornitsa' (clean, front half of the house). It was built on the 'podklet' (the lower floor of the house), which warmed the living space. In the early 18th century in Siberian cities were often built three-chamber dwellings, which consisted of warm pieces ( ' $i z b a$ ', 'gornitsa'), 'seni' (the space connecting the entrance to the house with the rooms) and 'klet' (cold part of the house, pantry). The peculiarity of the dwellings of Yeniseisk was the significant size of the area of buildings. The three-chamber structure reached a length of 18-19 meters, and the area of warm rooms $-6.5 \times 6.5 \mathrm{~m}$. The same size had the 'seni' and 'klets'. The total area of threechamber buildings was 130 sq. m. Almost every yard had buildings for keeping livestock and rooms for storing hay. In the courtyards of Yeniseisk there were buildings of two-tiered construction. In the description of the listed farm buildings, which were arranged under living spaces. This allowed rational use of the yard area and created convenience for household management. Baths were most often placed in the vegetable garden. They were large $4.3 \times 4.3 ; 6.4 \times 6.4 \mathrm{~m}$. Wells were built next to the baths. The yard was fenced a 'Zaplot' (horizontal half-logs or boards inserted with their ends in the grooves of the racks), and the vegetable gardens with a 'palisade'. Buildings were built with $\operatorname{logs}$ and frames. The roofs and floors of the buildings were made of 'tesa' and 'drani', which were made of split logs. Mica, rich deposits of which were located in the Yenisei district, was inserted into the windows. The construction of a large number of such buildings is explained by the knowledge and experience of Russian settlers, the abundance of forest material in Siberia.

\section{AUTHORS' CONTRIBUTIONS}

V. I. Tsarev performed a scientific analysis of the identified archival materials. Systematization of information 'Census book of Inns of Yeniseisk' allowed V. V. Tsarev to perform a graphical reconstruction of the buildings of the city yard, 
typical for villages in Central Siberia the turn of the 17 th and 18th centuries ("Figure 2").

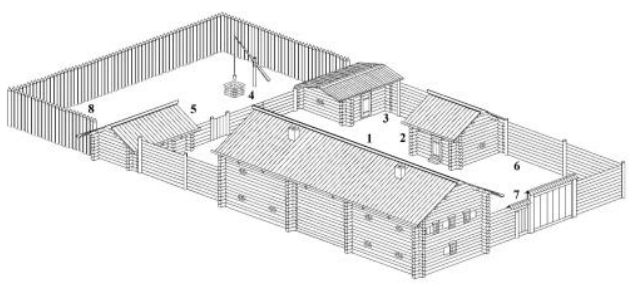

Figure 2 Building of the yard in the villages of the Yenisei district of the turn of the 17th and 18th centuries. 1 - two of the 'gornitsa' on the 'podklet' and a 'seni'; 2 - a barn; 3 - a cattle shed; 4 - a well; 5 - a bathhouse; 6 - a 'zaplot'; 7 - a gates; 8 - the vegetable garden fenced a 'palisade'.

- Graphic reconstruction of the authors

The creation of a scientific database of the architectural and urban heritage of Yeniseisk is the basis for the concept of forming a regional historical, cultural and tourist complex in Central Siberia.

\section{REFERENCES}

[1] Siberia of 18th century in travel notes by G. F. Miller. Novosibirsk. Publishing house 'Siberian chronograph', 1996, p. 39. Sibir' XVIII veka $v$ putevyh opisaniyah G. F. Millera. [In Russian].

[2] Russian state archive of ancient acts. Rossiiskii gosudarstvennyi arkhiv drevnikh aktov. Fund 214. Inventory 3. Case 12. S. 350-351. [In Russian].

[3] Russian state archive of ancient acts. Rossiiskii gosudarstvennyi arkhiv drevnikh aktov. Fund 214. Inventory 3. Case 25. S. 41 [In Russian].

[4] Russian state archive of ancient acts. Rossiiskii gosudarstvennyi arkhiv drevnikh aktov. Fund 214. Inventory 3. Case 6. S. 42 [In Russian].

[5] Russian state archive of ancient acts. Rossiiskii gosudarstvennyi arkhiv drevnikh aktov. Fund 214. Inventory 3. Case 307. S. 506 [In Russian].

[6] Russian state archive of ancient acts. Rossiiskii gosudarstvennyi arkhiv drevnikh aktov. Fund 214. Inventory 3. Case 505. S. 272 [In Russian].
[7] V.V. Tsarev, V.I. Tsarev, Reconstruction of the fortifications of the Yenisei ostrog in 1667 in: Wooden architecture: New materials and discoveries. Issue 6. Saint-Petersburg: Kolo, 2018, 82-98. Rekonstrukciya ukreplenij Enisejskogo ostroga 1667 goda [In Russian].

[8] Russian state archive of ancient acts. Rossiiskii gosudarstvennyi arkhiv drevnikh aktov. Fund 214. Inventory 3. Case 1397. S. 406 [In Russian].

[9] Russian state archive of ancient acts. Rossiiskii gosudarstvennyi arkhiv drevnikh aktov. Fund 214. Inventory 1. Case 1357. S. 110 [In Russian].

[10] Russian state archive of ancient acts. Rossiiskii gosudarstvennyi arkhiv drevnikh aktov. Fund 214. Inventory 1. Case 1374. S. 113 [In Russian].

[11] Russian state archive of ancient acts. Rossiiskii gosudarstvennyi arkhiv drevnikh aktov. Fund 214. Inventory 1. Case 1417. S. 19 [In Russian].

[12] D.Ya. Rezun, A.Khr. Elert, Siberian cities as historical and cultural monuments of the 18th century (based on the materials of the Second Kamchatka expedition) in: Monuments of history, culture and urban development of Siberia. Novosibirsk: The science. Siberian branch, 1991, 5-25. Sibirskie goroda kak pamyatniki istorii i kul'tury XVIII v. (po materialam Vtoroj Kamchatskoj ekspedicii) [In Russian].

[13] Russian state archive of ancient acts. Rossiiskii gosudarstvennyi arkhiv drevnikh aktov. Fund 214. Inventory 1. Case 207. S. 1 [In Russian].

[14] Russian state historical archive. Rossiiskii gosudarstvennyi istoricheskii arkhiv. Fund 1399. Inventory 1. Case 723. S. 1 [In Russian].

[15] Russian state military historical archive. Rossiiskii gosudarstvennyi voennoistoricheskii arkhiv. Fund 846. Inventory 16. Case 19107. S. 202 turnover [In Russian].

[16] Russian state archive of ancient acts. Rossiiskii gosudarstvennyi arkhiv drevnikh aktov. Fund 214. Inventory 1. Case 1390. S. 13-25 turnover [In Russian].

[17] Ibid., s. 15. 